\title{
Urban Planning, Smart Growth, and Economic Calculation: An Austrian Critique and Extension
}

\author{
SAMUEL R. STALEY \\ samuelrstaley@aol.com \\ The Buckeye Institute for Public Policy Solutions, 88 E. Broad Street, Suite 1120, Columbus, OH 3215 and Reason \\ Public Policy Institute, Los Angeles, CA
}

\begin{abstract}
This paper takes a critical look at the Smart Growth movement and its reliance on traditional central planning to achieve its goals. Using statewide planning in Oregon, Florida, and Washington State as examples, the paper examines the planning focus of recent efforts to manage growth through land-use planning at the state level. It then applies the Austrian critique of economic planning to the contemporary Smart Growth movement in the United States as it is reflected in statewide planning laws. The calculation debate focused primarily on the technical question of whether bureaucratic planning could, in fact, achieve market outcomes. In the current debate over Smart Growth, planning combines political and bureaucratic decisionmaking. The political context in which planning decisions are made fundamentally alters the decision making process, shifting the emphasis to articulate knowledge as the foundation for policymaking. To be relevant in the current debate over planning, the calculation debate needs to be extended to include a political dimension to its critique of planning.
\end{abstract}

Key Words: urban planning, growth management, central planning

JEL classification: $\quad \mathrm{R} 14, \mathrm{R} 52, \mathrm{R} 58, \mathrm{P} 11, \mathrm{P} 16, \mathrm{H} 11$

\section{Introduction}

The resurgence of popular support for planning is difficult to ignore in the current political climate. More than 37 states are considering major planning and land-use reforms, and a dozen others have adopted "strong" statewide planning laws (Salkin 1999, 2000). These laws typically require local governments to adopt comprehensive land-use plans and tie them to state goals and objectives, often codified into law through a growth management act or law (GMA). Practical issues associated with growth - traffic congestion, loss of open space, higher infrastructure costs, environmental quality — have provided a political climate conducive to increasingly centralized land-use planning. Most of the support for the new wave of planning reform, however, is based on abstract goals and concepts, not an understanding of their practicality.

This paper focuses on the practical aspects of implementing conventional urban planning ideas using the socialist calculation debate as a context and general framework. Modern planning reforms are rooted in conventional planning concepts, and, as such, they tend to minimize or even ignore the practical issues surrounding implementation. The next section discusses Smart Growth and the core elements that appear to anchor the current wave of policy reforms. Florida, Oregon, and Washington State are used as examples for how these planning reforms manifest themselves in practice. Section 3 then presents the basic 
outlines of the socialistic calculation debate and the core of the Austrian critique of planning. Section 4 applies the Austrian critique to Smart Growth by focusing on the dynamic and political dimensions of planning implementation. Section 5 concludes with a brief summary of the main points of the paper.

\section{Smart Growth and Urban Planning}

The most heralded case of state and local growth management may be Oregon, the first geographically diverse state to implement a statewide planning law. The Portland metropolitan area, in particular, has become a national model for regional growth management, engaging in top-down land-use and transportation planning since 1979 through its urban-growth boundary (Knaap and Nelson 1992, Howe 1993:61-73). More recently, it has instituted a regional land-use plan, the 2040 Plan, that emphasizes compact, transit-oriented, mixed-use development, and density standards to encourage high-density development. Other states have taken different approaches, from top-down state action in Florida to more decentralized and bottom-up approaches in Georgia and Tennessee.

While the detail and style of Smart Growth shifts, many of the common themes include a significantly expanded role for local and regional political control over growth (Staley 2001b). This political control manifests itself in a greatly enhanced role for traditional planning. Planning requires the establishment of formal goals and the identification of a set of strategies for achieving those goals. In the context of growth management, these goals may be defined specifically (e.g., a maximum city size of 75,000 ) or generally (e.g., promote "sustainable" development or "livability"). A set of strategies is identified that uses a mix of non-market growth-management tools such as urban-growth boundaries, zoning, building permit caps, density requirements, or urban-design standards.

Portland, Oregon has the most developed set of growth-management strategies in place within the United States. Its regional growth boundary hems in a 3-county urban area of about 2 million people. In the early 1990s, the city embarked on an aggressive growth-management plan that identified growth corridors, designated employment and population centers, and invested heavily in public transit (Mildner 2001). While initial growth-management policies encouraged higher densities by eliminating maximum density limitations, concern that market-driven development was not generating sufficiently high densities led to the imposition of a minimum density (maximum lot size) standard of 8,500 square foot lots in the late 1990s (Staley, Edgens, and Mildner 1999). The 2040 growth-management plan is rooted in an ideal-type of the city that borrows heavily from the urban form of European cities and early 20th century American cities.

Interestingly, while Oregon's statewide growth management law is one of the most comprehensive, it lacks specificity. Communities are required to implement urban-growth boundaries and adopt comprehensive plans that account for a number of different issues (e.g., enviromental protection, curbing urban sprawl, etc.), but the statewide plan provides little concrete guidance. In Washington State, on the other hand, growth-management hearing boards have settled on a standard maximum lot size of a quarter acre as the criteria for determining whether development is "sprawl". In Oregon, local communities are expected to set standards. Thus, Portland's approach is unique even within Oregon. Moreover, the 
State of Oregon engages in little program evaluation. The state does not collect data on a statewide basis to evaluate progress local communities make toward achieving their planning goals. Thus, Portland is a national model of planning because it has taken the planning mandates the furthest.

\subsection{The Case of Florida}

While Oregon established statewide planning goals, Florida emerged as one of the nation's leaders by placing "consistency" among state, regional, and local plans at the heart of its planning efforts. The Growth Management Act of 1985 serves as the primary vehicle for this reform (DeGrove and Metzger 1993). The State and Regional Planning Act of 1984 instituted a system of integrated state, regional, and local planning and mandated the development of the first state comprehensive plan (SCP), completed in 1985 (DCA 2000). The Act also required Regional Planning Councils (RPCs) to prepare and adopt Strategic Regional Policy Plans (SRPPs) consistent with the state plan.

The Florida legislature enacted the Environmental Land and Water Management Act in 1972, creating a program to protect areas of critical concern and to regulate developments that would have regional impact (DCA 2000:7). This was the state's first foray into growth management, and, like other states, placed environmental protection at the heart of its growth-management efforts. The legislature then enacted the Local Government Comprehensive Planning Act of 1975, which required local governments to develop comprehensive plans. However, the law did not tie local plans to a statewide plan, vision, or goals. Because Florida's planning did not integrate local, regional, and statewide goals into comprehensive planning, many planners believed the requirements were too loose to be effective.

The GMA of 1985 built on these legislative efforts, vertically integrating planning at three levels of government. On the state level, the SCP directs policy at all levels of government and requires state agencies to develop agency plans to implement some of its elements. The SCP is prepared by the governor's office and is reviewed every two years. The SCP sets forth the long-range goals, objectives, and policies to guide future growth in Florida, though it does not contain a future land-use map. It contains numerous goals and policy statements in 26 broad areas (Figure 1). On the regional level, RPCs adopt regional policy plans consistent with the state plan, but tailored to regional conditions.

On the local level, all counties and municipalities are required to adopt state-approved local comprehensive plans consistent with the state and regional plans. Each local government prepares a comprehensive plan for state review and approval that consists of at least 11 elements: Housing Affordability, Capital Improvements, Future Land Use, Traffic Circulation, Sanitary Sewer, Solid Waste, Drainage, Potable Water, and Natural Groundwater Aquifer Recharge, Conservation, Recreation, Housing, Intergovernmental Coordination, and Coastal Management. Local plans must also include periodic monitoring and evaluation procedures, and local development regulations must be adopted that are consistent with the comprehensive plan. If a local government does not prepare a required plan element, a Regional Policy Council (RPC) is required to develop and adopt the missing elements. The GMA of 1985 also required local development regulations to be consistent with the local plan, authorized the use of financial sanctions against jurisdictions failing to adopt 
1. Education

2. Children

3. Families

4. The elderly

5. Housing

6. Health

7. Public safety

8. Water resources

9. Coastal and marine resources

10. Natural systems and recreational lands

11. Air quality

12. Energy

13. Hazardous and nonhazardous materials and waste
14. Mining

15. Property rights

16. Land use

17. Downtown revitalization

18. Public facilities

19. Cultural and historic resources

20. Transportation

21. Governmental efficiency

22. Economy

23. Agriculture

24. Tourism

25. Employment

26. Plan implementation

Figure 1. Statewide planning goals for the State of Florida.

consistent plans, and required citizen participation in the planning process (DCA 2000). All of Florida's local governments have now adopted comprehensive plans that comply with the GMA of 1985.

The "consistency" requirement creates an additional burden on the real-estate market that increases incremental costs. Since local plans must be consistent with the state plan, it is difficult to change local plans to reflect shifting market conditions. In addition to the heightened politicization of the process, local communities would also need to get approval from the state (e.g. the DCA).

The state Department of Community Affairs (DCA) is responsible for reviewing local plans and ensuring that they are consistent with the state plan, regional plans, and the state planning goals. The importance of state review of local plans was evident early in the process. Most local governments were required to submit their plans for DCA review between 1989 and 1991. Of the 399 cities that submitted plans, DCA determine that 211 were inconsistent with the goals and requirements of the GMA and returned to their respective cities for revisions (Staley and Gilroy 2001). Among the state's 67 counties, only 10 were in compliance (Staley and Gilory 2001). In some cases, cities negotiated with the DCA for three or four years before their plans were in compliance.

Originally, many thought the Florida growth-management system would be bottom up since local governments were responsible for developing their own growth management plans. The DCA, however, has gone beyond ensuring the local plans are technically in compliance. It also evaluates whether it believes the plan will, in fact, be effective in meeting the goals of the GMA (Holcombe 2001). This may explain why more than half of the plans submitted by Florida cities and counties were rejected by DCA.

To amend its comprehensive plan, the local government must hold a public hearing in which it formally decides to forward a plan amendment to DCA for review. After DCA reviews the amendment and offers comments, the local government must hold a second public hearing at which it makes a final decision on adopting the amendment. If adopted, the amendment is sent back to DCA for a compliance review to ensure consistency with 
the state and regional plans. Upon completion of the compliance review, DCA will publish a "Notice of Intent" in the local newspaper stating its decision. Appeals of DCA's findings are forwarded to the Division of Administrative Hearings to initiate a formal proceeding, and, depending on the outcome, ultimately may be sent to the Administration Commission for a final decision. In short, virtually any change in a local plan must be approved by a state agency.

Initially, the most controversial element of Florida's GMA was "concurrency": The requirement that local governments provide adequate public facilities concurrent with new development (Holcombe 1990). As part of the local planning process, local governments are required to delineate those areas intended for urban facilities and services, and local governments are not allowed to issue development permits until they can demonstrate their ability to fund and construct the infrastructure necessary for the new development. The concurrency requirement applies to roads; water, sewer, and drainage systems; solid waste; parks and recreation; and, if appropriate, mass transit systems. ${ }^{1}$

Florida also adopted a compact development policy to discourage large-lot development, and this policy was codified into a rule requiring local governments to conduct a needs analysis estimating the gross acreage needed in each land-use category in anticipation of projected population growth. The rule also requires a cumulative land-use analysis that considers the "extent, location, distribution, intensity, compatibility, suitability, functional relationship and demonstrated need of each land use type" (DCA 2000). The purpose of this analysis is to evaluate whether the local plan meets the compact development policy goals. The DCA, as mentioned above, also evaluates the plans based on whether it believes the plan will likely achieve the goals established in the GMA of 1985. Communities with plans falling short of these goals can recommend changes to the future land-use map or the adoption of additional strategies to prevent urban sprawl.

\subsection{The Case of Washington State}

Washington State provides yet another model of statewide planning. As a response to an increasing public demand for controls on urban development, the Governor created the Growth Strategies Commission (GSC) in 1989 to recommend a statewide growth-management strategy. One year after the formation of the GSC, the Washington legislature enacted the Growth Management Act of 1990, the state's first comprehensive attempt at statewide growth management. Washington's GMA requires counties (and the cities within them) to adopt comprehensive plans, tie zoning to those plans, adopt urban-growth boundaries, and meet specific planning criteria (APA 1996b:4). Unlike Oregon and Florida, however, not all counties were required to plan under the GMA. Only large urban counties that experienced population growth of 10 percent or more during the previous decade and counties that experienced growth of 20 percent or more were required to plan. Small, slow-growing, and rural counties could opt out of the state growth-management process.

The 1990 GMA required all counties to adopt a critical areas preservation plan and a county plan to preserve and conserve resource lands, but only 29 of the state's 39 counties are engaged in comprehensive planning and development control under the Act. Eighteen of these counties are required to plan under the GMA, while 11 have chosen to plan even though 
they do not meet the criteria for mandated planning. An "opt in" provision thus became an important feature of statewide planning in Washington. ${ }^{2}$ Voluntary planning, however, is not unique to Washington State. New Jersey began implementing a statewide planning in 1992, although only 11 percent of the state's local governments participate (Staley 1999). Other states, such as South Carolina, have passed laws requiring local planning, but have not tied planning to statewide goals.

Counties that meet the GMA planning criteria are required to:

- Adopt a county-wide planning policy;

- Designate and adopt regulations conserving critical areas, agricultural lands, forest lands, and mineral resource lands;

- Designate urban growth areas (UGAs); and

- Adopt a comprehensive plan within a specified time frame.

Washington's growth-management process hinges on 14 planning goals embedded in state law (Revised Code of Washington (RCW) 36.70A.020; RCW 36.70A.480) that guide the development and the adoption of local comprehensive plans and development regulations (Figure 2).

The cornerstone of Washington's growth management plan is county planning. Unlike Florida and Oregon, almost all planning is developed and executed at the county level, with minimal state oversight. The state develops population growth forecasts for the state, and then "allocates" them to counties. Each county is then legally responsible for accommodating this projected growth through the local planning process. How this growth is

1. Encourage development in urban areas where adequate public facilities and services exist or can be provided in an efficient manner;

2. Reduce urban sprawl;

3. Encourage efficient multimodal transportation systems coordinated with local comprehensive plans;

4. Encourage the availability of affordable housing to all income levels and promote a variety of residential densities and housing types;

5. Encourage economic development consistent with adopted comprehensive plans;

6. Protect private property rights;

7. Process development permits in a timely, fair and predictable manner;

8. Maintain and enhance natural resource-based industries and encourage the conservation of productive forest and agricultural lands;

9. Encourage the retention of open space and the development of recreational opportunities;

10. Protect the environment and enhance the state's high quality of life;

11. Encourage citizen participation in the planning process;

12. Ensure that public facilities and services necessary to support development shall be adequate at the time of development;

13. Encourage historic preservation; and

14. Ensure consistency with the provisions of the Shoreline Management Act of 1971.

Figure 2. Statewide planning goals for Washington State. 
accommodated (e.g. through higher densities, urban-design criteria, zoning, etc.) is left to the discretion of the counties and their municipalities. To date, unlike Florida, the state has merely checked plans for their technical compliance with the GMA.

County plans can include requirements as specific as residential density standards, distribution of housing types, commercial and industrial land allocations, and priority development locations within UGAs. Thus, the GMA encourages counties and their local governments to be involved in detailed planning of the urban physical landscape. In addition, as part of the fiscal analysis, counties are required to work with municipalities to determine both the amount of buildable land located within their jurisdictions and future land needs (PSRC 1998:1). Counties have substantial discretion over whether cities are planning in accordance with the spirit and letter of the GMA. If the county determines a city's plan does not meet the planning goals outlined in the CPP, it may require the city to adjust its land-use strategies. Finally, counties are required to establish a review and evaluation program to review local plans every five years (beginning in 2002) to ensure that they are providing the land, densities, and capital facilities necessary to accommodate growth.

Washington State's GMA suggests a development hierarchy in which new development should be located primarily in areas "characterized by urban growth" with existing public facilities and services, and secondarily in areas to be served by existing and proposed urban facilities and services. Within UGAs, jurisdictions are required to protect critical and sensitive areas, plan for greenbelts and open space areas, and provide for urban densities of at least four units per acre. Over time, land within UGAs should be incorporated within cities for the provision of urban services; municipal annexations are not allowed beyond designated growth areas. ${ }^{3}$

The primary tool for implementing Washington's growth-management goals is the comprehensive plan. Every county and city must adopt a comprehensive plan that is guided by the GMA's 14 planning goals. Each comprehensive plan must include several "elements" or sections that address specific policy issues: land use, housing, capital facilities, utilities, and transportation. Consistency, ensuring goals and strategies complement or do not contradict each other, is required internally within plans as well as between city and county plans.

The land-use element must include a future land-use map, designations of planned population densities and building intensities, and estimates of population growth. The GMA also encourages the use of land-use management techniques such as density bonuses, cluster housing, planned-unit developments, and the transfer of development rights (APA 1996b). Each jurisdiction is also required to identify lands for essential public facilities, such as airports; schools; utility, transportation, and open-space corridors; landfills and sewage treatment facilities; and recreation facilities.

All elements of the comprehensive plan must be consistent with the future land-use map. And all comprehensive plans are subject to continual review, evaluation, and amendment under GMA, although plan amendment may occur no more than once per year. The GMA also requires that the plan adoption and amendment process incorporate substantive public involvement.

The comprehensive plan provides the framework for regulating development in each county and city, but each jurisdiction is also required to adopt development regulations 
(such as zoning ordinances, subdivision regulations, and critical areas ordinances) to implement the plan. Development regulations must also protect the natural resource lands and critical areas that jurisdictions are required to designate. Consistency also requires a plan amendment for changes in development regulations, such as rezoning.

\subsection{Housing and Planning}

Housing provides an example of how planning envisioned by the GMAs is applied in practice. Oregon's legislation requires all cities and jurisdictions to comprehensively plan their cities and address 19 state-specified goals. The housing goal [OAR 660-0150-0000(10)] requires communities to plan for a diverse range of housing needs and types. The "housing element" of the comprehensive plan must include an analysis of the distribution of the current population by income and housing-unit cost, vacancy rates, a forecast of housing demand, an allowance for a variety of densities and housing types, and inventory units capable of rehabilitation. Cities must also ensure that enough land exists within their urban-growth boundaries to meet the needs of households of all income levels. Given the level of detail and attention paid to housing in this legislation, the lack of understanding or discussion of how the planning process influences the housing market is surprising, suggesting a disconnection between growth-management goals and growth-management implementation.

Local governments in Florida are responsible for preparing projections of new households by size and income range, conducting an assessment of housing and land needs tied to those projections, and designating sufficient sites at appropriate densities to accommodate the need for affordable housing (Florida Administrative Code). Florida cities and counties are also directed to avoid concentrating affordable housing in specific geographic areas. Florida's administrative rules governing the implementation of the GMA also require the local housing element to be consistent with the housing goals and policies in the state comprehensive plan. The state's plan includes limiting housing discrimination, developing policies that encourage housing opportunities for all state residents, and increasing the supply of safe and affordable housing for low- and moderate-income populations (Anthony 2000:142).

Housing and housing affordability are also important elements of Washington State's growth-management legislation. One of the Washington GMA's fundamental goals is to "encourage the availability of affordable housing to all economic segments of the population, promote a variety of residential densities and housing types, and encourage the preservation of existing housing stock." To achieve this goal, comprehensive plans must include affordable housing policies, and the housing element of these plans must include an inventory and analysis of current and projected housing needs, an identification of sufficient land for housing, and adequate provisions for needed housing at all income levels.

\subsection{Summary}

The modern wave of growth-management legislation has several common characteristics with traditional centralized economic planning. Among the more salient features are: 
- Closed systems and hierarchies. Planning is done in a "closed" framework where means and ends are simultaneously determined. This closed system establishes a hierarchy for urban form and land development issues are largely divorced from the preferences of consumers. This explains, in part, why GMAs include so many goals, many of which may be inconsistent with each other. In order to be comprehensive, growth-management laws need to consider as many different facets and impacts of growth as possible. Moreover, these goals are tied to specific policies. The result, however, is a system vulnerable to significant outside shocks if some goals or unintended consequences are not adequately addressed (e.g., supply-side shifts in the housing market or higher planning costs).

- End-state planning. Planning is motivated by an ideal end-state-a vision of an ideal form and conception of how the community will function. In most cases this end state is higher density and more traditionally urban than currently found in conventional suburbs. Even here, however, the end-state is often envisioned in contradictory ways. In some cases, the vision is positive-the city's future form is specified. In other cases, the end state is expressed negatively as excluding certain types of development (e.g., development of large rural, open spaces).

- Complete knowledge. The presumption underlying Smart Growth and most planning law reform is that that all the relevant factors for determining housing demand and supply, land availability, and the interrelationships between commercial, industrial, and residential land development are known and foreseeable. Uncertainty is rarely acknowledged or addressed. Thus, comprehensive plans are adopted with the intention they will be modified on rare occasions (often once or twice a year), and amendments are subject to onerous review and approval processes. In some cases, amendments can only be approved by voter approval. Little innovation or spontaneity is permitted or accommodated.

- Political optimization. Planners and policymakers are expected to include all the relevant information in their decisions about what kinds of factors influence the growth of a community, and that all relevant preferences will be revealed accurately and optimally through the political process. Importantly, the legislative role in policy making offsets the technical role played by professional planners.

\section{The Economic Calculation Debate Revisited}

Urban planning as incorporated into state and local GMAs is strikingly similar to the planning envisioned by socialists in the 20th Century. GMA's require communities to draft detailed land-use plans and, in some cases, urban-design criteria, using 5-, 10-, 20-, and even 40-year visions for economic growth. These plans are supposed to be regulated by a series of bureaucratic and political controls, including minimum densities, formulas for housing types, and publicly funded programs.

This suggests that the issues underlying the debate over economic calculation in the 20th Century may be relevant to the discussion of Smart Growth in the 21st Century. The 20th century debate focused primarily on the role of public planning as it applied to the national economy. Advocates of economic planning argued that the primary problem faced by decision makers was technical: obtaining the information that consumers wanted and incorporating that information into production decisions. This argument has resurfaced in 
the context of modern computers and memory that allow calculation at ever greater speeds and precision (Horwitz 1996).

The critics of planning, represented by Austrian economists such as Ludwig Von Mises and F.A. Hayek, agreed that the problem was one of economic calculation, but that formal public planning was inherently incapable of collecting or processing the information that would be socially relevant. Producers (and by extension planners) are faced with a "knowledge problem," understanding what consumers want and finding the most efficient means for producing those goods and services. Knowledge itself is comprised of two components: articulate and inarticulate (Lavoie 1985). Articulate knowledge represents the tangible expression of wants and preferences. This is the kind of information that could be gleaned from market surveys, focus groups, or interviews with buyers. Moreover, this is information that can be objectively measured. In the residential housing market, objective information could include criteria such as the size of a preferred house in square feet, the number of bedrooms, the size of the lot, access to shopping or work in time or linear miles, etc.

The more important component, however, is inarticulate or implicit knowledge. While consumers may be able to express certain aspects of their preferences, other key ingredients may not be articulable. Often, customers will buy a product based its look or feel and an expectation about whether that product will satisfy their needs. Some of this inarticulate knowledge may be aesthetic; other aspects may be functional. In the real-estate market, how a house sits on a lot may have important impacts on the perception (or expectation) of privacy, or its functionality (e.g., steep driveways in winter climates). Similarly, objective criteria may not be able to capture key aspects of a neighborhood that are important to future residents and consumers.

Actual buying behavior reflects a complex interaction of articulate and inarticulate knowledge. Part of the consumer's decision reflects an assessment of measurable tradeoffs-how much lot is the consumer willing to trade off for the size of a house? Other parts of the decision are inarticulable or unknowable - will this house serve the needs of a growing family? These are tradeoffs that consumers make based on objective information, experience, expectations about future events, and personal preference. Inarticulate knowledge is the source of most uncertainty in the market and the primary component of its dynamic nature. Articulate knowledge by its very nature can be measured and, in theory, be forecasted with a reasonable degree of precision.

Market prices serve as an intermediating data point that provides summary information to consumers about products (and potential revenue for producers). (Horwitz 1998) The decision to purchase (or produce) a product depends on a synthesis of our understanding of preferences as well as hunches, "feelings," and judgements based on inarticulable information from experience. Economic preferences can only be known when they are "revealed" through their decisions about what to buy and for how much. The inarticulate knowledge cannot be replicated in formal planning, and thus accurate predictions or forecasts about consumer buying patterns are virtually impossible.

Markets, in contrast, are capable of processing this knowledge because of the dynamic institutional context in which consumer information is processed. Money prices provide a commonly accepted metric that intermediates between entrepreneurs and consumers who can act only on partial information. Money facilitates these transactions because it 
is tangible, has a commonly accepted value (under a stable monetary regime), and is fungible. Thus, movements in prices emerge as reflections of the subjective values of consumers and producers about goods and services available in the market (Horwitz 1998).

But the information provided by market transactions in not completely transparent. On the contrary, entrepreneurs are constantly looking for market opportunities "missed" by others (Kirzner 1973). Thus, the market process is an institution of discovery, where buyers and sellers are constantly assessing what customers want, what consumers are willing to pay for, and what production methods most effectively and efficiently provide those goods and services (Hayek 1978). The dynamism of the market process allows the revealed preferences of consumers to be incorporated into future decisions on both the producer and consumer side of the ledger. The market is disciplined by the profit and loss system (absent third-party intervention such as a government).

Thus, the perceived "order" of the market is a macro phenomenon that results from incremental decisions made by individuals using marginal economic calculations. It is a spontaneous order - a product of human action by not human design. Moreover, the changes in the market reflect these incremental changes among consumers and producers. In some cases, these changes can be revolutionary. The adoption of mass-production housing techniques ushered in sweeping changes in housing style and choice during the late 1940s and 1950s when large-scale suburbs such as Levittown were created. By 1950, almost all homes built in the United States were single-story ranches, a dramatic break from the artisan-based production methods prior to World War II (Baxandall and Ewen 2000).

While visionaries such as William Levitt may be able to occasionally spur widespread changes in a market product, most economic activity is less sweeping. In most cases, the changes are incremental and well suited to the marginal calculus of a dynamic profit and loss system. For example, once the basic pattern of the suburban tract home was established, Levitt and other housing entrepereneurs made incremental changes to their product as they tailored it to increasingly sophisticated tastes. Future homes had choices of facades, appliances, and larger living spaces. The first homes came with an optional carport, but future homes also provided for garages. At first, Levitt's pioneering approach to housing focused almost exclusively on functionality. As the market matured, his homes focused more and more on aesthetics. Levitt, like other homebuilders, had to adapt his product to meet changing consumer demands, and the signals he received through market prices and purchasing patterns provided the guideposts he needed. The market, then, is uniquely suited to handle economic problems that are inherently uncertain, environments that are dynamic, and products that are heterogeneous (Staley 2001b). Formal planning could not make the adjustments necessary to meet changing market demands because it lacked an institutional ability to process inarticulate information in a meaningful sense.

This conception of the real-estate market is in stark contrast to the one implied in state and local growth-management laws. The subjective, marginal calculations (and their efficiencies) implicit in market decisions are ignored in the modern growth-management movement. On the contrary, most laws and ordinances presume the efficiency of a certain type of housing and lot size. As the housing sections of these growth-management plans make clear, housing markets are reduced to relatively simple and narrowly defined categories: high density, medium density, low density, rural, "affordable". In some cases, growth management 
statutes/ordinances mandate specific design criteria. Growth-management policy is driven by the average calculations of the development approval process, not marginal calculations of consumers or housing entrepreneurs.

The calculation debate, however, provides only a limited lens through which modern urban planning policy can be analyzed. The 20th Century debate focused narrowly on economic calculation in a dynamic, macro context. Modern urban planning focuses on specifying finely grained changes in the land market based on large, abstract principles. Growth-management plans are concerned with more than the pace of growth; they are concerned with the pattern and location of growth.

Perhaps more importantly, the calculation debate largely ignored the role of politics in fundamentally changing the decision environment. The debate was largely technical: could the market or professional planners more effectively provide goods and services to consumers? In the modern Smart Growth movement, land-use decisions are effectively moved outside both the economic and bureaucratic realms. Professional planners are not trusted with planning any more than private entrepreneurs are. The final outcome is arbited through a legislative process rooted in Representative Democracy. This is particulary true in the United States, but similar trends toward more political (and less bureaucratic) control over land-use are also visible in Europe (Staley 1994).

\section{Politics, Economic Calculation, and Plan Implementation}

Thus, a solid grounding in political economy is missing from the Austrian critique of planning. The planning problem faced by decisionmakers is not simply one of economic calculation. The nature of the problem is altered by the environment in which the decisions are made. In the context of Smart Growth, even if planners were technically able to specify the future growth of communities, the political environment in which policy decisions are made fundamentally alters the outcome and reduces the stability of the decision making process. In fact, this is in part the purpose of moving traditionally economic decisions into the collective realm: the private actions of individuals in economic markets generate politically undesirable outcomes. ${ }^{4}$

The institutions of collective decision making in representative democracies such as the United States are based on the principal of majority rule. This rule sets up a zero-sum game, where one party (or coalition) can reap significant rewards through rent seeking (Staley 2002). The outcome of collective decisions themselves are based largely on persuasion, the ability to articulate positions and outcomes in ways that convince a majority of legislators or city councilors (either individually, through log-rolling, or coalition building) to formally adopt a position and vote for legislation. The persuasion may be based on value judgements, abstract concepts, or empirical evidence. The logic of collective action in a political context has three important implications for decision making and plan implementation.

First, marginal calculations are less important than average calculations. The focus of political activity will be on raising the average outcome for the winner. Those with narrower interests will find coalition building difficult since coalitions require broad-based and abstract agreement to be successful. A coalition may come together as a voting block based on the principle of affordable housing even though they may not agree on a particular type 
of housing (e.g., apartments versus scattered site single-family detached homes). The key constituencies may come together with the expectation they will all get a share of the newly allocated pie. Thus, minorities and those with finer grained tastes and preferences will tend to be marginalized politically through collective decision making.

Second, the legislative process shifts the emphasis from inarticulate to articulate knowledge as part of decision making. Articulate knowledge by its nature is broader and less nuanced; the nature of articulate knowledge is to have enough shared meaning among varied members of the coalition or group that there is a common understanding of the goal to be achieved. Inarticulate knowledge is more personalized knowledge that is unique in its understanding and application; it emerges from experience, and only those who have the shared experience can find the same meaning. Thus, as a growth-management plan is implemented, the kinds of information that will figure prominently in the political debate and evaluation will be articulable, tangible, and measurable. Products will be treated as if they are homogenous. Thus, housing will get lumped into categories using criteria such as price and density, and the nuance and value of individual units will be largely ignored. In the political process, the heterogeneous nature of products, particular those as differentiated as housing, will become less and less important since the focus is on larger, more abstract goals. The object is to increase the perceived average social welfare of the majority. This strategy is successful in a zero-sum environment where entrepreneurship is not allowed.

This can be seen in the debate over housing prices in Portland, Oregon. Portland experienced dramatic increases in housing prices during the 1990s. Many analysts attribute a substantial portion of this housing-price increase to the region's growth boundary since it has restricted the supply of land (Staley, Edgens, and Mildner 1999), although others have attributed rising housing prices to a speculative bubble (Phillips and Goodstein 2000). Even if housing prices have remained consistent with market trends, however, the quality of housing has gone through a significant change. For example:

- The region now has a lot-size standard of less than 8,500 square feet, or one-eighth of an acre;

- Lot sizes have fallen 25 percent since the early 1990s (Staley, Edgens, and Mildner 1999, Staley and Mildner 1999);

- Multi-family housing has emerged as the dominant form of homebuilding (Staley Edgens and Mildner 1999); and

- Higher land prices led homeowners to trade off smaller lots for larger homes (Conder and Larson 1998).

Regional planning provides few tools for handling such significant changes in housing quality. Growth-management plans may have established housing targets, but they are unable to match these housing targets with known or perceived housing preferences. Growthmanagement plans have no effective way to regulate planning policies to ensure they are consistent with the preferences of homeowners.

Third, the institutional environment of decisionmaking on the local level is biased toward maintaining the status quo (Staley 2001b). Most participants in the development-approval process are focused on the immediate impacts of a proposal on their welfare. Planning boards and city councils are composed of existing residents, not future homeowners or 
renters. Most public hearings are attended by current residents that will be directly (and often negatively) effected by the proposal. The benefits of a development proposal to future residents as well as future benefits to existing residents are significantly discounted. Thus, when diffuse, intangible benefits in the future are weighed against the anticipated negative impacts of current residents, elected officials often err on the side of being conservative and maintaining the status quo. This tendency is reinforced by (1) a development-review process that subjects most major development proposals to public review and comment, and (2) a comprehensive plan amendment process that presumes any change to the adopted land-use plan requires an affirmative case for approval. Market changes are presumed to have a negative impact on the community and must therefore be justified, stifling spontaneity and innovation in the housing market.

This has profound implications for the practicality of planning. Since collective decisionmaking relies on formal arguments and data, the development-approval process necessarily limits the relevant information to that which can be demonstrated objectively or articulated in a public process. Moreover, by subjecting development projects to a public hearing, significant uncertainty is injected into the final decision on whether to allow the project to proceed. Of course, this presumes that the collective-decisionmaking process works smoothly and, in fact, serves the public interest (broadly defined). These problems are compounded by the inadequacy of existing data and analytical techniques to allow for "noise" both in the specification of the models as well as in their interpretation.

While comprehensive planning attempts to shape the physical landscape of a community, the planning process also entails costs (Staley 2001a, Lai 1997). Inconsistencies between planning and market demand can result from several factors, including:

- Poor and inaccurate population forecasts, such as higher-than-expected population growth;

- Unexpected changes in household composition such as higher-than-anticipated numbers of households without children or more single-parent households;

- Unbalanced zoning for particular uses, such as too little large-scale retail or too much office development; or

- Misjudged housing trends and styles, such as condominiums versus single-family homes with yards.

Any of these planning failures will force developers into a higher-cost discretionary review process that ultimately could impact the cost and quality of housing. Higher prices are particularly likely in strong housing markets where developers will adjust by either raising prices to cover new costs or reducing the number of units they produce. If the comprehensive plan misjudges market trends, or requires land-uses inconsistent with current consumer demands (e.g. higher densities than the market will bear), developers will be faced with substantial costs as they attempt to re-tailor proposals to both the comprehensive plan and the consumer's desires.

Again, these concerns are not simply abstractions. The Florida GMA includes a policy directive regarding compact urban development with the intent of discouraging urban sprawl, improving infrastructure to support redevelopment and infill development, and discouraging urban development in rural areas (DCA 2000). These planning goals may be at odds with 
the actual preferences of Floridians, who prefer low-density development along its lakes and rivers and dispersed urban centers, reflecting its automobile orientation (Audirac, Shermyn, and Smith 1990:470-482). This may create conflict as builders and developers attempt to create housing consistent with consumer preferences while the formal planning process supports housing that is not consistent with consumer preferences and thus circumvents the real-estate market.

Compliance with the comprehensive planning process may, in fact, exacerbate housing price trends. An county-level analysis of housing in Washington State and Florida found that compliance with the GMA could account for 26 percent of the housing price growth in Washington State between 1995 and 2000 and 20 percent of the price growth in Florida between 1994 and 2000 (Staley and Gilroy 2001). More importantly, the planning unit of analysis was the number of years each county had been in compliance with the law. In Florida, counties that came into compliance later had lower housing price growth than counties that complied more quickly.

This suggests a persistent imbalance between housing supply and demand. While housing markets are in continual adjustment, statewide planning laws inhibit land market adjustments even further by creating a presumption against proposed changes to the existing land-use map and comprehensive plan. Since adjusting growth-management laws is time consuming, amendments tend to be rare and sporadic. The amendments tend to increase the role of legislative decisionmaking and reduce the spontaneity of the housing market. Thus, the information issues are compunded by a political tendency to expand formal planning even further. Statewide planning laws were themselves the product of environmental laws that were considered "deficient." Now, growth-management laws are being reformed as elected officials are disappointed by the results.

For example, Washington State's growth-management program was modified in 1995 to address unintended side effects on housing development and affordability, particularly those in the growing Seattle-Tacoma metropolitan area. These changes include streamlining the environmental review process, clarifying the allowable size and location of urban-growth areas using local market factors, and encouraging multi-family residential development in certain urban areas. The 1995 modifications also included provisions to enhance the protection of existing single-family residential neighborhoods.

Communities have also felt pressure to expand the array of programs that specifically address housing-market issues. According to the Washington State Department of Community, Trade and Economic Development (CTED), communities statewide are using a variety of mechanisms to ensure an adequate supply of affordable housing, including:

- Expanding the range of allowable lot sizes;

- Allowing manufactured housing on individual lots;

- Providing density or height bonuses for including affordable housing in a project;

- Encouraging infill development and rehabilitating older buildings;

- Establishing minimum densities in residential zones;

- Encouraging mixed-used development;

- Allowing accessory dwelling units in single-family residential areas;

- Offering market-rate housing with some units reserved for low-income housing;

- Offering tax incentives for multi-family housing in urban centers; 
- Encouraging urban design that blends increased densities in existing neighborhoods; and

- Allowing townhomes and "zero-lot-line" homes (homes built out to lot boundaries with little space between them).

Note also the following example from Eugene, Oregon (City of Eugene 2000). Eugene adopted 19 growth-management policies in 1998 to guide the city's work programs, including budgeting and revising its capital improvement plan. The report also declared its intention to diversify housing types within the city, increase densities, and use design standards, open space, and housing-maintenance programs to mitigate any possible impact, including increases in housing prices. The first nine policies focus on increasing density within the city's urban-growth boundary, encouraging infill and mixed-use development (downtown and elsewhere), improving the appearance of buildings, and preventing sprawl. In 1998, the city began "land-banking" to preserve space for low- and moderate-income housing to supplement its direct housing subsidies to tenants and builders. In February 2000 , the city made almost $\$ 2$ million available for new housing projects for low-income families. The plan makes almost no provision for ensuring that the supply of housing in the private market stays sufficiently high to mitigate housing-price escalation, despite the fact that the city is one of the least affordable housing markets on the West Coast.

Another case in point is Ventura County, California. Already one of the least affordable regions in the nation, Ventura County adopted growth boundaries for its ten cities through a series of growth-management initiatives in the 1990s. The growth boundaries were intended to preserve rural land outside urban areas. Yet, cities within the county continue to approve housing development at densities half the level anticipated in the comprehensive plans (Fulton, Williams, Mallory and Jones 2001). At current rates, most cities in Ventura County will achieve build out a full ten years prior to its 25 -year planning horizon.

\section{Conclusion}

A century ago, economists debated the merits of centralized economic planning on a national scale. The debate was primarily over the technical ability of formal economic planning to achieve the market outcomes. As the 21st Century begins, most economists have conceded the superiority of markets over planning in the macro economy.

The acceptance of markets as a superior mechanism for allocating scarce resources in the economy is in odd contrast to the current Smart Growth movement. Growth management is on the ascendance, and key features of planning reforms include the widening use of centralized land-use planning to control the pace and pattern of growth. Moreover, Smart Growth reforms also include a substantial increase in the politicization of the growth-control process.

The debate over economic calculation provides an important framework for assessing the likelihood the current wave of Smart Growth planning reforms will be successful. Market economies emerged as superior to planned economies because markets could coordinate the millions of decisions of consumers and producers efficiently. Markets were most effective in dynamic environments with heterogeneous products and services because they provided an institutional framework in which diverse, dynamic consumer preferences could be revealed 
and processed. The current wave of growth-management reforms, in contrast, ignores much of the heterogeneity of the housing market, subordinating diverse and nuanced consumer demands for housing to broader categories of housing that can be articulated through the political process. As a result, Smart Growth policies are likely to be unsuccessful because they will not be able to effectively coordinate these decisions in a way that captures the desires of consumers or adapts effectively to changing needs and circumstances.

\section{Notes}

1. Many critics of the GMA believed the concurrency requirement would place significant burdens on local governments and developers, primarily because the state legislature did not commit to funding infrastructure at the levels many felt would be necessary to finance roads, sewers, and water to accommodate expected new growth. In practice, the concurrency requirement has been less onerous than expected. The DCA has been flexible by allowing local plans and governments to trade off concurrency requirements with other goals, such as reducing urban sprawl or promoting urban infill (Holcombe 2001:126). Also, the legislature allowed local governments to identify concurrency areas where local developments could contribute to improve the transportation infrastructure.

2. Once counties begin planning under the GMA, they are required to adhere to GMA's planning mandates even if they no longer meet the criteria. Counties opting into the GMA are also required to meet the GMA's mandates once they have adopted a resolution committing to the process. In other words, while counties can opt in to the state planning process, they cannot opt out at a later point. Counties and cities are also allowed to form regional planning agencies. In fact, GMA requires multi-county planning policies for the Seattle and Tacoma metropolitan area-King, Pierce, Island, and Snohomish counties (PSRC 1998).

3. Whether the growth boundaries achieve these goals is the subject of considerable debate. In Oregon, Metro is faced with significant political pressure to maintain existing boundaries by mandating higher densities to prevent its expansion (Staley, Edgens, and Mildner 1999:19-23). Some experts have even questioned whether local governments are using the correct criteria for deciding when to expand the growth boundary (Knaap and Hopkins 2001). Clearly, urban growth boundaries present a policy dilemma. On the one hand, statewide growth-management laws require governments to expand housing choice and improve affordability. On the other hand, urban-growth boundaries limit the supply of land and can potentially increase the cost of housing, or significantly reduce its quality by limiting specific types of housing (e.g. affordable homes on a one-third-acre lot).

4. Note this is not meant to imply the market outcomes are not welfare enhancing. Rather, it acknowledges that the political market may operate under different principles than economic markets.

\section{References}

APA (2001a) "Growing Smart ${ }^{\text {SM }}$ Statutory Planning Summary for the State of Florida" (May 1996 update), www.planning.org/plnginfo/growsmar/summary/fla.pdf, June 20.

American Planning Association (APA)(2001b) "Growing Smart ${ }^{\text {SM }}$ Statutory Planning Summary for the State of Washington (May 1996b)," www/planning.org/plnginfo/growsmar/summry/washing.pdf. June 19.

Anthony, Jerry (2000) The Impacts of State Growth Management Regulations on Housing Prices and Housing Affordability in Florida. Tallahassee, Florida: Florida State University, College of Social Sciences, Department of Urban and Regional Planning, Summer 2000.

Baxandall, Rosalyn and Ewen, Elizabeth (2000) Picture Windows: How the Suburbs Happened. New York: Basic Books.

Conder, Sony and Larson, Karen (1998) Residential Lot Values and the Capital-Land Substitution ParameterSome Recent Results from the Portland Metro Area. Growth Management Services Division, Metro, unpublished paper, Portland, Oregon, May. 
DeGrove, John M. and Metzger, Patricia M. (1993) "Growth Management and the Integrated Roles of State, Regional, and Local Government." In: Stein, Jay M. (Ed.) Growth Management: The Planning Challenge of the 1990s, pp. 3-17. Newbury Park, California: Sage Publications.

Downs, Anthony (2001) "What Does 'Smart Growth' Really Mean?" Planning (April), http://www.planning.org/pubs/plng01/april012.htm.

Edgens, Jefferson G. (2001) "National Land-use Planning Through Environmental Policy.” In: Holcombe and Staley (Eds.) Smarter Growth, pp. 95-112.

English, Mary R., Peretz, Jean H., and Manderschied, Melissa (1999) Smart Growth for Tennessee Towns and Counties: A Process Guide. Knoxville, Tennessee: Energy, Environment and Resources Center, University of Tennessee, February 1999, http://eerc.ra.utk.edu/smart/title.htm.

Eugene, City of (2000) Growth Management Implementation Projects. Status Report for 2000, Eugene, Oregon. Florida Administrative Code, Chapter 9J-5k. "Housing Element."

Florida Department of Community Affairs (DCA) (1999) Affordable Housing Study Commission Final Report 1999. Tallahassee, Florida.

Florida Department of Community Affairs (DCA) (2000) Growth Management Program-A Comparison of Selected States, www.floridagrowth.org/pdf/states.pdf, July 31.

Hayek, F. A. (1978) "Competition as a Discovery Procedure.” In: New Studies in Philosophy, Politics, Economics, and the History of Ideas. Chicago: University of Chicago Press.

Holcombe, Randall G. (1990) "Distributional Aspects of Florida's Concurrency Requirement." Florida Policy Review, 5(Winter): 8-14.

Holcombe, Randall G. (2001) "Growth Management in Action: The Case of Florida." In: Holcombe and Staley (Eds.) Smarter Growth, pp. 131-154.

Holcombe, Randall G. and Staley, Samuel R. (Eds.) (2001) Smarter Growth: Market-Based Strategies for Land-use Planning in the 21st Century. Westport, CT: Greenwood Press.

Horwitz, Steven (1996) "Money, Money Prices, and the Socialist Calculation Debate." Advances in Austrian Economics, 3: 59-77.

Horwitz, Steven (1998) “Monetary Calculation and Mises's Critique of Planning." History of Political Economy, 30(3): 427-450.

Howe, Deborah (1993) "Growth Management in Oregon." In: Stein, Jay M. (Ed.) Growth Management: The Planning Challenge of the 1990s, pp. 61-75. Newbury Park, California: Sage Publications.

Kirzner, Israel (1973) Competition and Entrepreneurship. Chicago: University of Chicago Press.

Knapp, Gerrit (1987) "The Price Effects of Urban-Growth Boundaries in Metropolitan Portland, Oregon." Land Economics, 61: 92-97.

Knaap, Gerrit J. and Hopkins, Lewis D. (2001) "The Inventory Approach to Urban Growth Boundaries." Journal of the American Planning Association, 67(3): 314-326.

Knaap, Gerrit and Nelson, Arthur C. (1992) The Regulated Landscape: Lessons on State Land Use Planning from Oregon. Cambridge, Massachusetts: Lincoln Institute for Land Policy.

Lachmann, Ludwig M. (1986) The Market as an Economic Process. New York: Basil Blackwell.

Lavoie, Don (1985) National Economic Planning: What is Left? Cambridge, MA: Ballinger Publishing Company.

Mildner, Gerard C. S. (2001) "Regionalism and the Growth Management Movement." In: Holcombe and Staley (Eds.) Smarter Growth, pp. 113-130.

Myers, Phyllis (1999) "Livability at the Ballot Box: State and Local Referenda on Parks, Conservation, and Smarter Growth, Election Day 1998." Discussion Paper prepared for The Brookings Institution, Center for Urban and Metropolitan Policy, January 1999.

Perkins Coie, The Washington Growth Management Act After Ten Years.

Phillips, Justin and Goodstein, Eban (2000) "Growth Management and Housing Prices: The Case of Portland, Oregon." Contemporary Economic Policy, 18(3): 334-344.

Puget Sound Regional Council (PSRC) (1998) The Washington State Growth Management Act with Applications for the Central Puget Sound Region. Forecasting and Growth Strategy Department.

Staley, Samuel R. (1994) Planning Rules and Urban Economic Performance: The Case of Hong Kong. Hong Kong: Chinese University Press/Hong Kong Centre for Economic Research.

Staley, Samuel R. (2001) "Ballot-box Zoning, Transaction Costs, and Urban Growth." Journal of the American Planning Association, 1: 25-37. 
Staley, Samuel R. (2001) "Markets, Smart Growth, and the Limits of Policy." In: Holcombe and Staley (Eds.) Smarter Growth, pp. 201-218.

Staley, Samuel R. (2002) “Zoning, Smart Growth, and Regulatory Taxation.” In: Donald P. Racheter and Richard E. Wagner (Eds.) Politics, Taxation, and the Rule of Law. Norwell, Massachusetts: Kluwer Academic Publishers. Staley, Samuel R. and Gilroy, Leonard C. (2001) Smart Growth and Housing Affordability: Lessons from Statewide Planning Laws. Policy Study No. 287. Los Angeles: Reason Public Policy Institute.

Staley, Samuel R. and Mildner, Gerard C. S. (2000) "The Price of Managing Growth." Urban Land, 59(2): 20

Salkin, Patricia E. (2000) "Smart Growth: The State of the States." Presentation to the Northeast State Planning Directors Meeting.

Salkin, Patricia E. (1999) "Smart Growth at Century's End: The State of the States." Urban Lawyer, 31(3): 601-648.

Lai, Lawrence W. (1997) "Property Rights Justifications for Planning and a Theory of Zoning." In: Diamond, D. and Massam, B. H. (Eds.) Progress in Planning: Recent Research on Urban and Regional Planning, pp. 161-246. Oxford, England: Pergamon Press. 